\title{
First field observations on the aestivation of Omphiscola glabra (Gastropoda, Lymnaeida) uninfected or infected with Fasciola hepatica in central France
}

\author{
D. Rondelaud*, P. Vignoles, G. Dreyfuss
}

UPRES EA n 3174, Facultés de Médecine et de Pharmacie, 2 rue du Docteur Raymond Marcland, 87025 Limoges, France.

\begin{abstract}
Field investigations on 12 populations of Omphiscola glabra were carried out in central France over a 5-year period to determine the ability of the species to aestivate in its habitats when summer drying occurred. In the department of Haute-Vienne, spring-born snails aestivated with their apertures applied to the surface of a substratum and most of them were located on the banks of ditches. With the return of wet conditions, the survival of these snails was low. In the department of Indre, most springborn snails aestivated by burrowing into the marl and were distributed over the whole surface area of their habitats. Higher survivals were noted for these $O$. glabra after aestivation. Despite a significant difference in the frequencies of buried lymnaeids, the position of snails with a natural infection with $F$. hepatica in their dried habitats was similar to that found for uninfected ones. The variations found in the aestivation of $O$. glabra might be explained by the dominant substratum (granite gravel and scarce mud in Haute-Vienne, or a thick layer of marl in Indre) and the plant cover on ditch bottoms.
\end{abstract}

Keywords : aestivation, burrowing, Digenea, Fasciola hepatica, Haute-Vienne, Indre, Lymnaeidae, Mollusca, Omphiscola glabra.

\section{Introduction}

In western Europe, the snail Galba truncatula (O.F. Müller) is known to be the principal intermediate host of the trematode Fasciola hepatica (Linnaeus). Another snail species : Omphiscola glabra (= Lymnaea glabra O.F. Müller) is also implicated, and natural infections of this species with $F$. hepatica were found in central France (Abrous et al. 1999, 2000). Populations of both snails often occur in the same swampy meadows on acid soil. The habitats of $G$. truncatula are confined to the peripheral extremities of open drainage furrows, while those of $O$. glabra are located in their middle part (Vareille-Morel et al. 1999). However, other sites, such as roadside ditches, can be colonized by the two species.

\footnotetext{
* corresponding E-mail: rondelaud@pharma.unilim.fr
}

The knowledge of the ecology of these snails is of great interest to consider the developmental phase of $F$. hepatica within snails, and to envisage fasciolosis control by isolating lymnaeid habitats from cattle or sheep. If the factors involved in the ecology of G. truncatula are well known (e.g., Boray 1969), those influencing the behaviour of $O$. glabra are still misjudged, as this species is more aquatic than $G$. truncatula. Some investigations on the ecology of O. glabra, and particularly on the ability of snails to survive long periods in dry soil are thus necessary. Preliminary studies on the habitats of $O$. glabra demonstrated the existence of variations in snail aestivation. In the department of Indre (central France), numerous O. glabra were burrowing in road ditches when stagnant water disappeared at the onset of aestivation, while no burrowing snail was observed in the ditches of Haute-Vienne (Rondelaud, unpublished data). Considering these preliminary findings, the following questions are raised : what was the post-summer survival of $O$. glabra in Indre and Haute-Vienne after the return of wet condi- 
tions in September? What was the distribution of snails uninfected or infected with $F$. hepatica in dried habitats at the end of August? To answer these two questions, a 5-year field study was carried out between 1996 and 2000 , to determine the ability of $O$. glabra to aestivate in their habitats when summer drying occurred.

\section{Materials and methods}

A total of 12 populations (Fig. 1) was selected for this study, as natural infections of $O$. glabra with $F$. hepatica were found in several dissected snails in 19941995. Five populations inhabited different roadside ditches located in the commune of Migné, department of Indre. The substratum of each ditch was constituted by a $10-15 \mathrm{~cm}$ deep layer of marl and was covered with slow-running water from October to mid-July. The seven other populations lived in roadside ditches in the neighbouring communes of Verneuil-sur-Vienne and Veyrac, department of Haute-Vienne. Constituted by bare granite gravel and scarce mud, these sites were flooded from November to the end of June. The distance between the two groups of sites was $100 \mathrm{~km}$. Summer drying occurred for 5-6 weeks in the ditches studied in the department of Indre, while its duration ranged from 5 to 7 weeks in those prospected in the department of Haute-Vienne. Vegetation covered the dried ditches of Indre, whereas the bottom of snail habitats in the department of Haute-Vienne was often bare during summer drying.

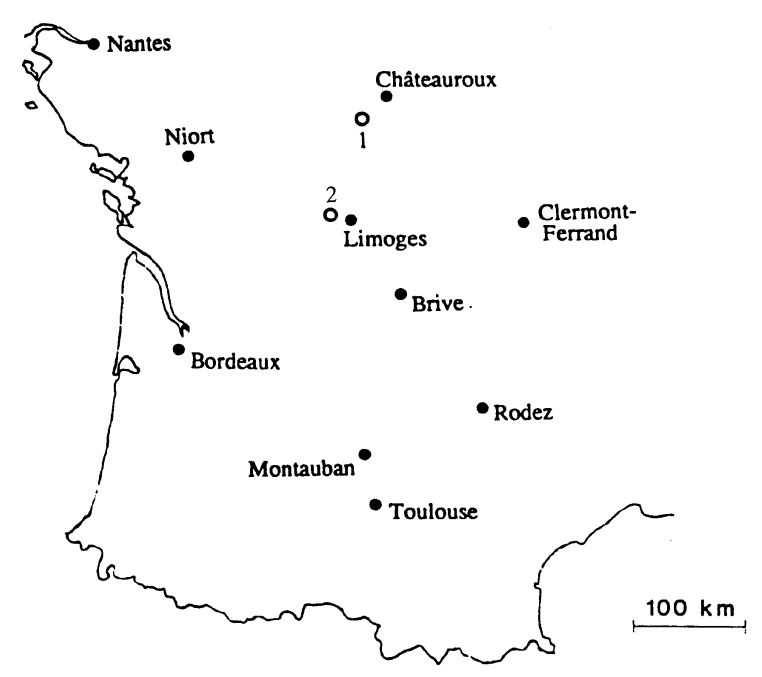

Fig. 1. Distribution of the 12 populations of Omphiscola glabra studied in central France.
Fieldworks were carried out in these 12 sites. The first survey was performed from 1996 to 2000 to estimate the density of live snails in each site at the beginning of July (before summer drying) and in September (just after the first rainfall). The second was effected in dried habitats at the end of August (1998, 1999, and 2000) to determine the location of surviving snails in each microhabitat (ditch bottoms, or slopes). The last investigation was done only in 2000 to specify the location of aestivating $O$. glabra in their habitats (snails buried into the mud, or attached to the surface of a substratum). Each snail was subsequently dissected under a stereomicroscope to determine natural infection with F. hepatica, or another trematode.

The three parameters studied in the first investigation were the survival of overwintering snails after aestivation, that of spring-born snails, and their shell lengths. Those recorded in the second survey were the percentages of aestivating snails found on the bottoms and sides of road ditches. In the last study, the parameters were the percentages of aestivating snails with shell apertures applied to a substratum (mud, plant, or other surfaces) and those of $O$. glabra buried into mud (in the 2-cm upper layer, between 2 and $4 \mathrm{~cm}$ in depth, or more than $4 \mathrm{~cm}$ ). The survival rates and the different frequencies noted in the two types of sites were compared using a Chi-square test, whereas one-way analysis of variance was used to determine levels of significance between the mean values of other parameters.

\section{Results}

In ditches located in the department of Indre (Table 1), the survival of $O$. glabra after aestivation extended from $46.4 \%$ to $66.5 \%$ for spring-born generation, and from $7.6 \%$ to $21.5 \%$ for overwintering snails. The range of survival rates found in the ditches of HauteVienne were $11.3-22.6 \%$ and 0.6-2.0 \%, respectively. A significant difference $(P<0.001)$ was detected between the percent values recorded in the former sites and those noted in the latter. Significant variations in relation with the year were found in the ditches of Indre $(P<0.001)$ and Haute-Vienne $(P<0.001)$ : the percentages recorded in 1997 in both departments were significantly lower, whereas clearly higher values were noted in 1998 (in Haute-Vienne) and in 1999 (in Indre). The shell lengths of spring-born snails were significantly higher $\left(F_{1.3706}=17.11, P<0.001\right)$ in the ditches of Indre, whereas there was no significant differences between the values recorded during the five years in each department. By contrast, in overwintering snails, the shell lengths did not show any significant variation between the two sites sampled. 
Table 1. Survival of Omphiscola glabra after aestivation, and range of shell lengths for overwintering and spring-born snails in the 12 ditches studied from 1996 to 2000.

\begin{tabular}{lcccccc}
\hline Department & $\begin{array}{c}\text { Year (study } \\
\text { area in } \mathrm{m}^{2} \text { ) }\end{array}$ & $\begin{array}{c}\text { No. of live } \\
\text { snails in July }\end{array}$ & \multicolumn{2}{c}{$\begin{array}{c}\text { Spring-born snails surviving in } \\
\text { September }\end{array}$} & $\begin{array}{c}\text { Overwintering snails surviving in } \\
\text { September }\end{array}$ \\
\cline { 4 - 7 } & & & Survival (\%) & Shell length (mm)* & Survival (\%) & Shell length (mm)* \\
\hline Indre & $1996(15)$ & 717 & 51.1 & $8.4 \pm 1.7$ & 11.2 & $21.5 \pm 3.7$ \\
& $1997(18)$ & 437 & 44.1 & $7.6 \pm 0.9$ & 7.6 & $18.7 \pm 4.5$ \\
& $1998(15)$ & 573 & 55.1 & $6.8 \pm 1.1$ & 12.2 & $19.2 \pm 5.4$ \\
& $1999(15)$ & 622 & 66.5 & $8.1 \pm 1.4$ & 21.5 & $20.5 \pm 3.1$ \\
Haute- & $2000(15)$ & 551 & 46.4 & $7.3 \pm 0.8$ & 11.8 & $19.6 \pm 2.9$ \\
Vienne & $1996(21)$ & 427 & 17.7 & $3.4 \pm 1.2$ & 0.6 & $16.5 \pm 0.7$ \\
& $1997(28)$ & 211 & 11.3 & $2.9 \pm 1.1$ & 0.6 & 15.4 \\
& $1998(21)$ & 535 & 22.6 & $3.7 \pm 1.4$ & 1.9 & $18.0 \pm 3.9$ \\
& $1999(21)$ & 378 & 20.3 & $3.3 \pm 1.0$ & 0.9 & $17.2 \pm 3.1$ \\
& $2000(21)$ & 356 & 15.7 & $3.1 \pm 0.7$ & 2.0 & $17.6 \pm 2.5$ \\
\hline
\end{tabular}

* Mean values \pm S.D

Table 2 shows the frequencies of aestivating $O$. gla$b r a$ in relation to their presence in the different parts of ditches (bottoms or banks). In the department of Indre, spring-born snails were distributed over the whole surface area of their habitats, while they were more numerous on ditch banks in the sites of Haute-Vienne. A significant difference $(P<0.01)$ between the percentages recorded in these two departments was noted. Significant temporal variations were also found in the former $(P<0.001)$ and latter $(P<0.001)$ sites. Contrary to their progeny, the distribution of overwintering snails did not show any significant variation in their dried habitats, whatever the department considered and the year of study.

The position of aestivating $O$. glabra in their habitats is given in Table 3 . In ditches located in the department of Indre, $76.0 \%$ of uninfected snails and $94.0 \%$ of lymnaeids infected with $F$. hepatica were buried into the soil, and their frequencies decreased with increasing depth of marl. Significant differences between these percentages and those of $O$. glabra

Table 2. Location of aestivating Omphiscola glabra at the end of August in different dried ditches located in the departments of Indre and Haute-Vienne.

\begin{tabular}{lccccc}
\hline Department & $\begin{array}{c}\text { Year (study } \\
\left.\text { area in } \mathrm{m}^{2}\right)\end{array}$ & \multicolumn{4}{c}{ No. of live snails (frequency in \%) } \\
\cline { 3 - 6 } & & \multicolumn{2}{c}{ Spring-born snails } & \multicolumn{2}{c}{ Overwintering snails } \\
\cline { 3 - 6 } & & $\begin{array}{c}\text { Ditch } \\
\text { bottom }\end{array}$ & Banks & $\begin{array}{c}\text { Ditch } \\
\text { bottom }\end{array}$ & Banks \\
\hline Indre & $1998(10.3)$ & $206(54.4)$ & $173(45.6)$ & $53(86.9)$ & $8(13.1)$ \\
& $1999(12.7)$ & $152(51.7)$ & $142(48.3)$ & $38(77.5)$ & $11(22.5)$ \\
& $2000(11.8)$ & $168(53.3)$ & $147(46.7)$ & $47(88.7)$ & $6(11.3)$ \\
Haute- & $1998(24.5)$ & $34(39.2)$ & $50(60.7)$ & $1(12.5)$ & $7(97.5)$ \\
Vienne & $1999(21.3)$ & $24(33.3)$ & $48(66.7)$ & $0(0)$ & $12(100)$ \\
& $2000(28.7)$ & $41(35.9)$ & $73(64.1)$ & $2(25.0)$ & $6(75.0)$ \\
\hline
\end{tabular}


Table 3. Location of aestivating Omphiscola glabra at the end of August on the bottom of different ditches located in the departments of Indre and Haute-Vienne.

\begin{tabular}{|c|c|c|c|c|}
\hline \multirow[t]{2}{*}{ Microhabitat features } & \multicolumn{2}{|c|}{$\begin{array}{l}\text { Ditches of Indre* } \\
\quad\left(21.8 \mathrm{~m}^{2}\right)\end{array}$} & \multicolumn{2}{|c|}{$\begin{array}{l}\text { Ditches of Haute-Vienne* } \\
\left(41.2 \mathrm{~m}^{2}\right)\end{array}$} \\
\hline & $\begin{array}{l}\text { Unin- } \\
\text { fected } \\
\text { snails } \\
(n=419)\end{array}$ & $\begin{array}{l}\text { Snails infected } \\
\text { with Fasciola } \\
\text { hepatica** } \\
(\mathrm{n}=51)\end{array}$ & $\begin{array}{l}\text { Uninfected } \\
\text { snails } \\
(n=267)\end{array}$ & $\begin{array}{l}\text { Snails infected } \\
\text { with } F \text {. hepatica } \\
\quad(\mathrm{n}=24)\end{array}$ \\
\hline \multicolumn{5}{|l|}{$\begin{array}{l}\text { Frequency }(\%) \text { of snails with } \\
\text { apertures applied: }\end{array}$} \\
\hline - to the surface of mud & 13.3 & 3.9 & 5.2 & 8.3 \\
\hline - to the surface of a plant & 21.5 & 1.9 & 63.3 & 70.9 \\
\hline - to others surfaces & 1.2 & 0 & 31.5 & 20.8 \\
\hline \multicolumn{5}{|l|}{$\begin{array}{l}\text { Frequency }(\%) \text { of snails } \\
\text { buried into mud: }\end{array}$} \\
\hline - in the upper layer & 39.3 & 76.4 & 0 & 0 \\
\hline - between 2 and $4 \mathrm{~cm}$ in depth & 17.7 & 17.6 & 0 & 0 \\
\hline - more than $4 \mathrm{~cm}$ in depth & 7.0 & 0 & 0 & 0 \\
\hline
\end{tabular}

which aestivated with their aperture applied to a substratum were noted for uninfected $(P<0.01)$ and infected $(P<0.05)$ snails. Comparison of frequencies recorded between uninfected and infected $O$. glabra only revealed a significant difference $(P<0.05)$ in the case of buried snails. In the ditches of Haute-Vienne, no buried snails were observed. Most $O$. glabra were found applied to stems or leaves. However, the distribution of these uninfected and infected snails in relation to their position on a substratum did not show any significant variation in their frequencies.

\section{Discussion}

In the department of Haute-Vienne, the colonization of ditch banks by numerous $O$. glabra at the onset of summer drying, and the low survival rates noted for post-aestivating snails fitted with the observations reported by Rondelaud \& Morel-Vareille (1975) for $G$. truncatula when their habitats dried in summer. If vegetation lacked in the bottom of ditches, numerous snails died, while the survivors took refuge under the nearest plants located on the banks and often aestivated with their aperture applied to the surface of stems and leaves. By contrast, in the department of Indre, the distribution of spring-born snails during summer drying occurred on the whole surface area of their habitats and the recorded survival rates for these lymnaeids after the return of wet conditions were higher. To explain this finding, two complementary hypotheses might be proposed. The first would be to relate these results to vegetation which grew in these sites, thus allowing the presence of a greater relative humidity for a long time. Another assumption is based on the physicochemical properties of marl, as this soil and its sizeable depth would probably offer favourable conditions for the survival of aestivating snails and their burrowing than gravel and mud found in the ditches of Haute-Vienne.

The burrowing of $O$. glabra in the soil during summer drying was already reported (Germain 1930/1931, Cheshire Amphibians 2002). As this process was not observed in the study sites in Haute-Vienne, we may wonder whether the behaviour of this snail was species determined, or if it was the response of an aquatic species to unfavourable conditions when the population lives in temporary habitats (on sedimentary soils). An argument supporting the second hypothesis is the rapid burrowing of snails into marl when their habitats were drying, even if stagnant water was still present in the bottom of ditches and could persist for a week or more 
before its disappearance. In the case of Haute-Vienne ditches, the absence of snail burrowing at the onset of summer drying might partially be explained by the rapid disappearance of stagnant water ( 1 or 2 days) in these sites, where most bottoms did not have any covering vegetation.

Apart a significant difference between the percentages of buried snails in the ditches of Indre, the distribution of other uninfected and infected lymnaeids in relation to their position on a substratum did not show any significant variation in terms of frequency distribution. The higher percentage recorded for infected $O$. glabra in the upper layer of marl was more difficult to explain because of the low number of naturally-infected snails (only 51) studied in the ditches of Indre. However, as the infected snails in another lymnaeid species : G. truncatula, were more dependent on water than uninfected lymnaeids (Rondelaud \& Vincent 1974), it might be assumed that infected $O$. glabra would have the same relationship with water and, consequently, would bury later than uninfected snails, i.e. only when stagnant water disappeared from their habitat. Under these conditions, burrowing of snails would be limited over time because of drying marl, thus inducing the concentration of most infected $O$. glabra in the upper layer of soil.

\section{References}

Abrous M., Rondelaud D., Dreyfuss G. \& Cabaret J. 1999. — Infection of Lymnaea truncatula and Lymnaea glabra by Fasciola he patica and Paramphistomum daubneyi in farms of central France. Vet. Res., 30, 113-118.

Abrous M., Rondelaud D. \& Dreyfuss G. 2000. — A field study of natural infections in three freshwater snails with Fasciola hepatica and/or Paramphistomum daubneyi in central France. J. Helminthol., 74, 189-194.

Boray J.C. 1969. - Experimental fascioliasis in Australia. Adv. Parasitol., 7, 95-210.

Cheshire Amphibians. 2002. — Distribution maps for aquatic snails in Cheshire. URL : http ://www.btinternet.com/ andyharmer/molluscs.htm - $10 \mathrm{k}$.

Germain L. 1930/1931. — Mollusques terrestres et fluviatiles. Faune de France $n^{\circ} 21$ et $n^{\circ} 22$. Librairie de la Faculté des Sciences, Paris : 897 p.

Rondelaud D. \& Morel-Vareille C. 1975. — Distribution estivale et survie des Limnées tronquées (Lymnaea (Galba) truncatula Müller) saines ou infestées par Fasciola hepatica L. Ann. Parasitol. Hum. Comp., 50, 603-616.

Rondelaud D. \& Vincent M. 1974. — Etude des migrations quotidiennes chez les Limnées tronquées (Galba truncatula Müller) saines ou parasitées par Fasciola hepatica L. Ann. Parasitol. Hum. Comp., 49, 411-416.

Vareille-Morel C., Dreyfuss G. \& Rondelaud D. 1999. - The characteristics of habitats colonized by three species of Lymnaea in swampy meadows on acid soil : their interest for fasciolosis control. Ann. Limnol., 35, 173-178. 